\title{
WHO IS POPULIST IN CENTRAL AND EASTERN EUROPE? A COMPARATIVE ANALYSIS OF PRIME MINISTERS' POPULIST DISCOURSE
}

BOJANA KOCIJAN ${ }^{1}$

\begin{abstract}
This article measures populist discourse among prime ministers in new Central and Eastern European democracies using holistic grading as a specific type of textual analysis. The article first offers a definition of populism and then measures political discourse by grading political speeches of contemporary prime ministers in Central and Eastern Europe. Next, it presents descriptive data about prime ministers' political discourse and discusses positive cases of populism in reference to democratic structures. Despite suggestions that we live in a populist zeitgeist, populism is a rare and occasional phenomenon in Central and Eastern European executive politics. It has often been associated with violations of democratic structure by individual leaders. However, these violations are more likely to be related to undemocratic political culture in general than to populism in particular. Where populism does coincide with an already undemocratic political mindset, this represents a more serious threat to democratic standards.
\end{abstract}

KEYWORDS: populism, discourse, textual analysis, prime ministers, Central and Eastern Europe

\footnotetext{
1 Bojana Kocijan has recently been awarded a Ph.D. at Central European University; e-mail: kocijan_bojana@phd.ceu.edu. This research was funded by the Political Science Department at Brigham Young University in Provo and was assisted by the Political Science Department at Central European University in Budapest. The author acknowledges the excellent research assistance of Elena Cristina Balea, Endre Borbáth, Craita Curteanu, Anna Forkovicova, Kristina Georgieva, Silvia Hudackova, Blagoy Kitanov, Katarina Klingova, Marko Kukec, Alexandra Claudia Manta, Tamás Molnár, Maja Pan, Inga Popovaite, Ardi Priks, Mihai Rosu, Mindaugas Savickas, Andras Schweitzer, Mārtinšs Sijāts, Izabela Surwillo, Orsolya Szabó, Allan Visor and Csilla Volford who undertook the holistic grading of prime ministers' speeches.
} 


\section{INTRODUCTION}

Despite several decades of research on populism, the concept remains something that everyone talks about, but no one really understands. For example, it is little understood why journalists or academics label some politicians populists. Principally, this is related to conceptual confusion about the meaning of populism, which consequently hinders its investigation and measurement. Nevertheless, in recent decades scholars have invested extensive effort into reaching an agreement about how populism can be defined, while at the same time they have tested different techniques for measuring individual or elite level populism.

Many scholars have warned about a rising tide of populism in CEE; however, we lack systematic comparative studies to support this argument. A number of electorally-successful populist parties are participating in executive politics across Europe (i.e. the Austrian Freedom Party, the Danish People's Party, the Italian Northern League, the Swedish Democrats, Hungarian Jobbik and Bulgarian Ataka). However, these populist forces are entering executive politics by capturing only a smaller share of votes, which makes them coalition partners, not coalition leaders. In CEE, however, several such political forces have entered mainstream politics by capturing the highest share of votes (i.e. Hungarian Fidesz, Bulgarian GERB, the Slovenian Democrats and the Polish Law and Justice Party). This does not mean that populist parties are fully absent from mainstream executive politics in Western Europe ${ }^{2}$, but rather that, in CEE, populist forces are more frequently participating in top executive politics.

This study is designed to examine the so-far neglected phenomenon of populism among party leaders who usually occupy prime ministerial posts once their parties win elections. Prime ministers, as the highest-ranking executive officers, have wide decision-making powers, which make elite level populism important in politics. This article's primary purpose is to provide descriptive data about the level of populism of a number of prime ministers. In doing so, it contributes to a larger debate in academia and the media about who rightly deserves to be labelled a populist, and why. It certainly makes sense to measure the level of populism of certain party leader/prime minister first, and only then analyze how and why it matters to politics.

The article starts by defining populism as a discourse. As a discourse,

2 For example, the Swiss People's Party has been the strongest party in the past few elections and Greek Syriza became the largest party after the 2015 elections. 
populism shares a Manichean ${ }^{3}$ vision of the world in which 'the people' are seen as inherently "good" and virtuous, while elites are inherently "bad' and corrupt. These two political subjects - the people and the elite - are in a constant cosmic struggle for power. Populists favor the overthrow of the unjust and corrupt elite through systemic changes that follow their rise to power (i.e. constitutional changes). The article then introduces holistic grading as a specific type of textual analysis that quantifies the populism of specific prime ministers using a three-point interval scale. The technique was developed by an American political scientist, Kirk A. Hawkins (2009) and has previously been used to measure the populist discourse of Latin American presidents. The method has proved successful in cross-regional comparisons of populist discourse by political leaders or parties through the holistic grading of political texts. In addition, compared to other manually coded methods of textual analysis, holistic grading is reasonably efficient for use on small and large samples and produces reliable data. Before concluding, the article presents data about the populist discourse of 27 contemporary prime ministers in eleven CEE countries during 30 prime ministerial terms and discusses positive cases in reference to the common understanding of populism, and briefly, in relation to the consequences this has on politics.

In contrast to the general impression that we live in a populist zeitgeist, data from this study indicate that CEE populism is a rather occasional and rare phenomenon. The holistic grading of political speeches identified strong populism in only one case, while only five contemporary CEE Prime ministers out of 27 turned out to be moderately populist. Previous studies have speculated about the causes of populism and its influences on democratic structure (Carpenter 1997; Gallina 2010; Bugaric 2008; Mesežnikov et al. 2008; Rupnik 2007). Data in this study suggest that the undemocratic lapses of CEE prime ministers might have more to do with a generally undemocratic political culture than populism alone. Nevertheless, where populism coincides with already undemocratic mindsets, the consequences for politics are more dangerous.

\section{POPULISM AS DISCOURSE}

The increasing amount of comparative research on populism has contributed to an emerging consensus that populism is best described as a set of ideas that

3 A Manichean worldview infers making a strong moral judgment about each single issue categorizing it into one of two clearly dualistic categories (i.e. good/bad, right/wrong). 
relates to seeing the world through Manichean glasses, juxtaposing the "will of the people" in a cosmic struggle with the conspiring elite (Hawkins 2009). In its ideational format, populism is not an exclusive discourse, but one of a number of other possible discourses, including pluralism and elitism. Table 1 distinguishes between populism and other political discourse.

Table 1. Types of political discourse

\begin{tabular}{|l|l|l|}
\hline Discourse & $\begin{array}{l}\text { Manichean } \\
\text { vision }\end{array}$ & People vs. Elites \\
\hline Populist & Present & 'The people' are more virtuous than the elite \\
\hline Pluralist & Absent & Commends diversity of ideas in society \\
\hline Elitist & Present & The elites are intellectually superior to 'the people' \\
\hline
\end{tabular}

The populist discourse embraces the Manichean vision in which virtuous people are in constant struggle against corrupt elites. This standpoint encourages the use of non-democratic means and the demonization of political opponents. Pluralist discourse is the theoretical polar opposite of populism, rejects the Manichean vision of the world as a struggle between the people and the elites, and embraces more universalistic themes. Unlike populism, pluralism favors the diversity of ideas and interests in society and encourages the acceptance of political opponents as political equals rather than political enemies. The elitist discourse shares populism's Manichean distinction between the people and the elite. However, elitism praises the elite as a selected group of individuals that is intellectually superior to the people as a result of which the elite, not the people, deserve to be in charge of the government (Mudde 2004; Hawkins 2009).

Conceptualizing populism as discourse ${ }^{4}$ not only allows us to develop suitable techniques for measuring populism, but to also ask theoretically relevant questions about why and how populism matters for politics and whether different discourses have concrete consequences on elections, policy outputs and the functioning of democracy. This approach to populism as discourse has already advanced research on populism in cross-regional studies through textual analysis, survey research and experiments (Jagers and Walgrave 2007; Rooduijn and Pauwels 2011; Hawkins et al. 2012; Schumacher and Rooduijn 2013; Vasilopoulou et al. 2014; Akkerman et al. 2014; De Waele and Cholova 2011; Deegan-Krause and Haughton 2009;

4 For a critique of populism as discourse and a discussion of other possible definitions of populism, see Hawkins and Rovira Kaltwasser (2013) 
Balcere 2014; Hawkins 2009). In addition, it has encouraged research into the causes of populism and its consequences by means of cross-regional comparative studies (Albertazzi and McDonnell 2008; Seligson 2007; Doyle 2011; Navia and Walker 2010; Hawkins 2012; Mudde and Kaltwasser 2012; Levitsky and Loxton 2013; Kriesi 2014; Mesežnikov et al. 2008; Tupy 2006; Gallina 2008). Nevertheless, systematic studies of populism are rare and those that apply to CEE have mostly focused on single cases or a limited number of cases (Jasiewicz 2008; Bozóki 2012; Bugaric 2008). In this respect, this study is an original attempt to measure the populist discourse of a larger number of individual CEE prime ministers.

What are the essential elements of populism as discourse? As a set of ideas, populism juxtaposes the notion of the people with an elite group, whom it sees as conspiring against the popular will for selfish purposes (Hawkins and Rovira Kaltwasser 2013, 4). A necessary condition for populism to exist, according to this definition, is a Manichean worldview by which virtuous people "crusade" against corrupt elites. This vision assigns a strong moral dimension to every issue and enables their categorization as "right"/"good" or "evil"/bad". A discourse may still be considered democratic because popular will is the primary source of power. However, populists understand popular will to be a unified whole, rather than allowing it to be whatever the majority of people decide at any particular moment.

The moral significance of issues is amplified by assigning cosmic proportions to threats evoked by a conspiring elite and a reified notion of history characterized by reverence for national/religious leaders. The nature of the conspiring/corrupt elite can differ according to context (including the opposition party, business elite, a foreign country or international institution i.e. the US, the EU or Russia), but may also arise in the form of an ideology (i.e. capitalism, colonialism, neoliberalism, communism or environmentalism). Populists usually favor systemic change and the overthrow of "corrupt" elite as a solution to the elite conspiracy against the people, even if change really comes only through elections. Finally, populists frequently justify nondemocratic means and use openly bellicose language towards their opponents.

In the pluralist discourse, issues are not framed in moral and dualistic terms, but focus on narrow and particular/pragmatic issues (i.e. the economy, budgets, taxation, education or infrastructure). The discourse favors natural differences of opinion and does not refer to any reified notion of history. Rather, temporal issues are limited to material reality and demystified connections are found to be more common. A pluralist speaker understands democracy to be a simple matter of vote-counting, rather than the emergence of a fixed, preexisting will. This discourse avoids the use of a conspiratorial 
tone and does not identify a single evil minority that is in charge. Even if it identifies an opponent, passions are muted and the tone is positive. Finally, a pluralist discourse does not favor systemic change but encourages the politics of difference over hegemony and emphasizes great respect for formal rights, the rule of law and democratic institutions.

\section{MEASURING POPULIST DISCOURSE}

The ability to measure the level of populist discourse among real political individuals across time and space not only adds scientific value to the definition of populism but also allows us to improve our knowledge about populism's causes and consequences. Only a handful of studies have measured populism in a systematic way, while most research into populism has focused on one case, or comparisons between parties or leaders in few countries, which does not allow for wider generalizations. When the above definition of populism as discourse is applied to the systematic analysis of political individuals through textual analysis, the end result is a dataset about discourse expressed in numerical scores for a large number of prime ministers across CEE (see Table 2).

The technique of the holistic grading of political speeches was developed and adapted by the American political scientist, Kirk A. Hawkins (2009) and was originally used to measure the political discourse of Latin American presidents. The holistic grading of political texts uses manual coders who are able to quickly analyze complex patterns of meaning and interpret whole texts, rather than smaller units of content such as words or sentences, which would be typical of standard computer or human-based content analysis. For the research described in this paper, the grading technique proceeded in three steps. First, we recruited individuals to read and interpret the political speeches of prime ministers in their native languages. We did not define any specific requirements for recruiting coders, except for their ability to speak the original language of the political speeches selected in our sample. We recruited about 50 native speakers of languages across Central and Eastern Europe who were pursuing an MA in political science at Central European University in Budapest in the spring of 2013. We then familiarized the coders with the preferred definition of populism and pluralism and equipped them with skills relevant to fill the rubric. The rubric (available upon request) served as a short coding guideline for readers to assist them in the holistic grading of the speeches and to ensure better data quality.

Grading alone can proceed quickly once coders are properly trained and 
once political speeches are available. The unit of analysis was a prime ministerial term, using four speeches selected non-randomly. ${ }^{5}$ After reading the text in its entirety (holistic grading), coders assigned a numerical score that best represented the discourse prevalent in each individual text. We used a three-point numerical scale, where zero represented a non-populist, namely a pluralist text, one represented a text that mixes elements of populist and pluralist discourse and two represented a speech where populist ideas were strongly expressed. During training workshops, we presented coders with several political speeches that had previously been graded so coders would become familiar with using the grades as guidelines when making decisions about individual texts. ${ }^{6}$

Two coders ${ }^{7}$ graded each individual speech after reading it in its original language. The final score for each prime minister presented in Table 2 represents the average score of both coders' scores across all four speeches. ${ }^{8}$ In addition, coders translated short citations from the original text to English and copied them in the relevant rubric's slots to denote populist or pluralist discourse. At the end of each rubric, coders provided short explanations about how elements of one or both discourses fared in individual texts. These short speech citations and summaries are the main source of qualitative data discussed below. The primary purpose of their inclusion is to support the numerical grades assigned to individual texts. Our data turned out to be highly reliable. After calculating the interclass coefficient that demonstrates how consistent different coders are relative to one another at measuring the same concept (on average), we learn that coders agree with each other about

5 We asked coders to find one speech for each of our four speech categories; a campaign speech (given during an electoral campaign), a ribbon-cutting speech (given at an opening ceremony with a small local audience), an international speech (given to an international audience, typically at the UN), and a famous speech (the most important or well-known speech that defined the career of individual leader).

6 We used a speech by Evo Morales (Bolivia) as an ideal type - score two - populist text, a speech by Steven Harper (Canada) as a speech that mixed elements of populism and pluralism - a score one example, and a speech by Tony Blair as an ideal type - score zero - pluralist speech.

7 To ensure inter-coding reliability coders did not see each other's scores before final meetings at which we discussed the scores together, hoping they would agree as much as possible on the scores assigned to individual texts.

8 Because not all categories of speeches were available for all prime ministers, the average score indicated in Table 2 reflects coding based on three speeches for Mečiar (Slovakia), Brazauskas (Lithuania) and Zeman (Czech Republic). 
90 percent of the time 9 ; a relatively high degree of agreement between the two coders of each individual speech.

\section{ANALYSIS OF THE DESCRIPTIVE DATA}

The cumulative result of our large-scale data collection effort is a data set about the political discourse of 27 contemporary prime ministers during 30 prime ministerial terms in eleven CEE democracies, as presented in Table 2.

Table 2. Prime ministers' political discourse

\begin{tabular}{|c|c|c|c|c|}
\hline Country & Prime minister & Coding applies to & Score & \\
\hline & & & Mean & s.d. \\
\hline Slovakia & Vladimír Mečiar ** & $1994-1998$ & 1.7 & 0.3 \\
\hline Czech R & Mirek Topolánek & $2004-2009$ & 1.0 & 0.5 \\
\hline Hungary & Viktor Orbán & 2010 - April 2013 & 0.9 & 1.0 \\
\hline Slovakia & Robert Fico & $2006-2010$ & 0.8 & 1.0 \\
\hline Slovenia & Janez Janša & $2004-2008$ & 0.8 & 0.6 \\
\hline Bulgaria & Boyko Borisov & 2009 - March 2013 & 0.6 & 0.5 \\
\hline Latvia & Einars Repše* & $2002-2004$ & $0.5^{* * * * *}$ & 0.6 \\
\hline Latvia & Aigars Kalvītis* & $2004-2007$ & 0.5 & 0.6 \\
\hline Croatia & Ivo Sanader & $2003-2009$ & 0.4 & 0.5 \\
\hline Hungary & Viktor Orbán & $1998-2002$ & 0.4 & 0.5 \\
\hline Romania & $\begin{array}{l}\text { Calin Popescu - } \\
\text { Tariceanu }\end{array}$ & $2004-2008$ & 0.4 & 0.8 \\
\hline Romania & Viktor Ponta & 2012 - April 2013 & 0.4 & 0.5 \\
\hline Slovakia & Mikuláš Dzurinda & $2002-2006$ & 0.4 & 0.8 \\
\hline Poland & Jarosław Kaczyński* & $2006-2007$ & 0.3 & 0.5 \\
\hline Romania & Emil Boc & $2008-2012$ & 0.3 & 0.5 \\
\hline Slovakia & Mikuláš Dzurinda & $1998-2002$ & 0.3 & 0.5 \\
\hline Lithuania & Algirdas Brazauskas** & $2001-2006$ & 0.2 & 0.3 \\
\hline Bulgaria & Sergei Stanishev & $2005-2009$ & 0.1 & 0.3 \\
\hline Bulgaria & Simeon Sakskoburggotsk & $2001-2005$ & 0.1 & 0.3 \\
\hline Czech R & Petr Nečas & 2010 - April 2013 & 0.1 & 0.3 \\
\hline Estonia & Andrus Ansip & $2007-2011$ & 0.1 & 0.3 \\
\hline Croatia & Ivica Račan & $2000-2003$ & 0 & 0 \\
\hline Czech R & Miloš Zeman*** & $1998-2002$ & 0 & 0 \\
\hline Estonia & Andrus Ansip & $2005-2007$ & 0 & 0 \\
\hline
\end{tabular}

9 The interclass correlation coefficient (ICC) was 0.87 with $95 \%$ confidence interval $(0.81-$ $0.91),[F(99,99)=7.9, p<0.000)]$. The ICC is calculated for the full grading sample minus Latvia and Poland where only one coder participated in holistic grading. 


\begin{tabular}{lllll} 
Estonia & Andrus Ansip & 2011 - April 2013 & 0 & 0 \\
Hungary & Ferenc Gyurcsány & $2004-2009$ & 0 & 0 \\
Latvia & Valdis Dombrovskis* & 2009 - April 2013 & 0 & 0 \\
Lithuania & Andrius Kubilius & $2008-2012$ & 0 & 0 \\
Poland & Donald Tusk* & $2011-$ April 2013 & 0 & 0 \\
Slovenia & Borut Pahor & $2008-2012$ & 0 & 0 \\
\hline Campaign speech*** & & & 0.7 & 0.7 \\
Famous speech & & 0.4 & 0.7 \\
Ribbon-cutting speech & & 0.2 & 0.4 \\
International speech & & 0.1 & 0.3 \\
\hline
\end{tabular}

Source: (Hawkins and Kocijan 2013. Dataset on political discourse among chief executives in CEE and Central Asia)

* Only one coder contributed

** Only three speeches available

*** Average score across all Prime Ministers in individual speech category

**** Scores of 0.5 and lower indicate isolated or weak elements of populism across prime ministers' speeches and a lack of explicit references to popular will or corrupt elite that is conspiring against the people. According to the definition of populism provided above, such references are preconditions for the awarding of a "populist" score ( 0.6 and higher).

Despite concerns raised by academics and journalists about the rising tide of populism, data from this study indicate that populism among chief executives in Central and Eastern Europe is an occasional and rare phenomenon. A varying degree of populism was confirmed by our analysis to exist among populism's usual suspects, ${ }^{10}$ including Mečiar in Slovakia, Topolánek in the Czech Republic, Orbán in Hungary, Fico in Slovakia, Janša in Slovenia and Borisov in Bulgaria. Accordingly, our data speak well to the common understandings of populism. The main contribution of this study, however, is its comparative analysis of a large number of cases with a varying degree of populism, which improves our knowledge as to how populist a leader is. This opens the window to new research about why and how populism matters for politics.

Findings from the Central Eastern European data resonate with findings about the populism of contemporary Latin American presidents. The incidence of populism in both data sets is almost identical, as is the intensity of populist discourse. In Latin America, ${ }_{11}^{11}$ only Hugo Chavez (1.8) in Venezuela and Evo

10 Our project also included two former presidents who were identified by preexisting literature as likely populists. Vaclav Klaus, in both his presidential terms (2003-2013), turned moderately populist with a score of 0.6 in his first and a score of 1 in his second term. We also confirmed the existence of moderate populism for the Polish Lech Kaczyński whose score was 0.8.

11 The holistic technique confirmed the populist discourse of several historical Latin American presidents, including Velasco Ibarra in Ecuador (1.7), Juan Peron in Argentina (1.5), Vargas in Brazil (1.0 in first and 0.9 in second term), Menem in Argentina (0.8), Saca in El Salvador (0.6) and Cardenas in Mexico (0.6) (Hawkins 2009). 
Morales (1.6) in Bolivia come close to ideal type populism. In CEE, only Vladimír Mečiar (1.7) in Slovakia is a "hard" populist, while all other prime ministers (with scores of 0.6 or higher) may be considered "soft "or only moderately populist, including Topolánek (1.0), Orbán in his second term (0.9), Fico (0.8), Janša (0.8) and Borisov (0.6). Similarly, except for Chavez and Morales in Latin America, only a few presidents are moderately populist, including Rafael Correa in Ecuador (1.3), Daniel Ortega in Nicaragua (1.3), Alan Garcia in Peru (0.8), and Mauricio Funes (0.6) in El Salvador. In both Latin American and CEE datasets, most prime ministers and presidents (see Hawkins and Rovira Kaltwasser 2013 for the Latin American dataset) turned out to be either weakly populist or pluralist. The holistic grading of political speeches by leaders in other regions was less systematic; hence, comparative conclusions about populism on a cross-regional basis are at present only preliminary. Some data about Western European leaders is available for Spain, Finland and Norway where prime ministers are predominately pluralist (Hawkins 2009). Holistic grading confirmed the existence of moderate populist discourse for only one Western European prime minister included in our sample, the Italian Silvio Berlusconi ${ }^{12}$ (Hawkins and Kocijan 2013).

Our data further suggest the importance of context-related factors that influence the emergence of populist discourse. Prime ministers are more likely to resort to populist discourse during electoral campaigns (i.e. prior to assuming executive posts) which is often the period when they are not part of the elite establishment but when they are competing to participate in government. Nevertheless, even during electoral campaigns, prime ministers' populist discourse appears only moderate, with an average score of 0.7 for all campaign speeches across all prime ministers. Once in office, however, prime ministers significantly tone down their populism, as indicated by the lower average scores for famous (0.4), ribbon-cutting (0.2) and international (0.1) speech categories. ${ }^{13}$ This can be explained by their newly-established elite status that makes anti-elite discourse less popular and supports the preexisting argument that populism is most prevalent among political outsiders, although further research in this area is certainly welcome.

12 Berlusconi's discourse during his first prime ministerial term (2001 - 2006) was expressed using a score of 0.8 and a score of 0.9 in his second prime ministerial term $(2008-2011)$.

13 We get almost identical average scores in individual speech categories across all prime ministers compared to the Latin American dataset (see Hawkins 2009, 1053). 


\section{ANALYSIS OF POPULIST PRIME MINISTERS}

The literature notes that populists and their governments are prone to authoritarian experiments and frequent violations of democratic norms. These violations are most often, but not exclusively related to openly challenging constitutional courts, curtailing the independence of the media, limiting the professionalism of the civil service and limiting constitutionallygranted minority rights (Bugaric 2008; Gallina 2010; Navia and Walker 2010; Levitsky and Loxton 2013; Mudde and Rovira Kaltwasser 2013). The following section discusses the qualitative data appraised by holistic grading that supports the numerical scores presented in Table 2 and analyzes how well these data relate to the authoritarian tendencies of populist prime ministers.

\section{Strong populists}

That Vladimír Mečiar in Slovakia is the only "strong" populist in CEE is hardly surprising. Mečiar's populism, authoritarian governing style, disrespect for democracy, misuse of the media and involvement in privatization scandals are well documented (Mesežnikov and Gyárfášová 2008; Bunce and Wolchik 2011; Deegan-Krause and Haughton 2009; Haughton 2002; Fish 1999; Gallina 2010). Elements of populist discourse are consistent across Mečiar's speeches and fit the category of nationalist populism. He juxtaposes the Slovak nation against any elite that challenges Slovakia's struggle for nationhood. In his campaign 1994 speech, he claims, ["our Slovakia will be healthier, stronger and happier" (...) "despite the anti-national propaganda claiming the opposite"]. In his famous 1998 speech, he portrays his HZDS as the "movement of the people, always in the service of citizens that never misused power". Identification of the conspiring elite varies across Mečiar's speeches. He was less specific about identifying conspiring elite in his campaign 1994 speech in which he hints at political opponents as "those who want to get personal benefits". However, he took a more aggressive stand towards the opposition in his famous 1998 speech where he labeled Dzurinda a "pseudo-economist with inclinations to polarize society and provoke scandals, favoring politics of revenge, prisons and terror", features common to the opposition elite, that is, according to Mečiar, composed of "gossipers, liars and haters". The demand for systemic change, including the centralization of authority and granting fewer powers to the president, was evident in his discourse. However, some pluralist ideas were also present in some of Mečiar's speeches. In a famous 
speech, given prior to the 1998 parliamentary elections, he emphasized his party "was in favor of a culture of tolerance, cooperation and not a society divided by ethnic lines" and expressed his willingness to "cooperate with everybody".

\section{Moderate populists}

Compared to Mečiar, Fico's populist discourse is less consistent. During his first prime ministerial term (2006 - 2010), he was often criticized for legislation that limited the investigative power of the media and for marginalizing Hungarian minority parties (Gallina 2010). The Manichean worldview is identifiable in his two moderately populist speeches. In his famous 2010 speech, he portrays Smer as "a defender of the Slovaks from potentially dangerous right-wing government" that will "implement policies against the interests of ordinary people and social stability". Similarly, in his ribbon-cutting 2003 speech, he portrays Smer as "protector of people's interests against energy monopolies". Fico also consistently demonizes political opponents across his speeches, except in his UN speech where his discourse is entirely pluralist. He accuses the opposition of engaging in illegal campaigning against Smer and in his campaign 2010 speech emphasizes, ["in a democratic country, it is not possible to respect someone who abuses the signature of the Prime Minister and the president of the strongest political party $(. .$.$) and "who engages in vote buying"]. .^{14}$

Topolánek's discourse in the Czech Republic is moderately populist across his speeches. His worldview is Manichean and his ODS party is framed in his campaign 2005 speech as "the savior of the people who should not be afraid anymore of various corrupt elites, including the socialist opposition and communists" that he compares to "cancer, black passengers and leeches who suck the life of the state". In his international speech (given in Estonia in 2008), he is a harsh critique of EU bureaucracy and Brussels policies that favor the old against the interests of new member states. However, despite his anti-EU discourse, he is not entirely against the EU but only critical of specific policies. The speeches of a decade-long Czech president, Vaclav Klaus, were also subject to holistic grading and confirmed his discourse as

14 Allegedly, one private company linked to the opposition party SaS put stickers on people's cars and motor vehicles instructing them "not to vote for the democratic left" (Fico's Smer) and offering them a ten percent discount on copy and fax services if they bring in unused voting ballots. 
only moderately populist. He is more specific in identifying the conspiring elite (i.e. the EU, global warming activists and environmentalists) than in referencing the people. He comes closest to populism when he emphasizes the EU's democratic deficits and the EU policies that limit people's freedoms and free trade. This finding resonates well with previous studies that have accused the Czech elite of euroscepticism (Gallina 2008). Anti-EU arguments prevailed over "us versus them" projections in the discourse by both Czech politicians who were also frequently accused by the media of dubious exclusionary rhetoric and alleged involvement in large-scale corruption scandals.

Hungarian Viktor Orbán adopted intense populist discourse in two out of his four speeches. He views the world through Manichean glasses, juxtaposing Hungarians against the socialist opposition elite and foreign powers (including foreign business interests, but also the EU). In famous 2012 speech Orbán states ["We will not be a colony" (...) "Hungarians won't live according to the commands of foreign powers; they won't give up their independence or their freedom" (...) "Colonizers of today are patiently stalking their targets" (...) "We know well the nature of undesirable comradely help, and we recognize it even if it does not come in military uniforms but in well tailored suits"]. Orbán also favored the overthrow of the existing socialist elite and compared the 2010 elections to the revolution, connecting it to the historical struggles of the Hungarians for freedom in 1848, 1956 and 1989. His discourse, however, did not encourage systemic change to fix elite injustices. Nevertheless, Orbán's authoritarian experiments with undermining checks and balances, changing the Hungarian Constitution and other undemocratic practices have been documented and have prompted some scholars to describe contemporary Hungary as a "simulated democracy" where democratic institutions exist, but where the elite engage in polarizing and increasingly norm-breaching confrontational behavior (Lengyel and Ilonszki 2012).

Janša's populism in Slovenia and his ambiguous democratic practices are well-documented and include attacks on constitutional court decisions, media freedom and involvement in corruption scandals (Rizman 2006; Bugaric 2008). A Manichean vision is evident throughout his speeches. Slovenians are assigned essentially virtuous qualities and are juxtaposed against corrupt elites that are either old communist nomenclature or Janša's socialist-liberal opposition. He mixes elements of nationalist and populist discourse and is more specific in identifying the conspiring minority than in referencing the people. In his campaign 2004 speech, for example he praises Slovenian nationhood "We fought for it, we grew up in it and we learned in it". One Slovenian scholar described Janša's discourse as radical populism, close to 
demagoguery, and Janša as a familiar example of an East European dissident - an anticommunist authoritarian (Rizman 2006).

Borisov in Bulgaria was accused of involvement in various corruption scandals, money laundering, attacks on media freedom and connections to organized crime, xenophobia and extremism. Previous research identified him as a populist who capitalizes on anti-corruption campaign (De Waele and Cholova 2011). Based on holistic grading, Borisov's populism is moderate and of a weak populist nature. A Manichean vision is not consistent across his speeches but is clearly identifiable where it does exist. In his famous 2013 speech, he portrays his GERB as an embodiment of the people, emphasizing, "We came into power because of the will of the people" and describing himself as a common man who "loves to walk with the people". The conspiring elite in Borisov's speeches is almost always the opposition. In his ribbon-cutting 2012 speech, he claims, "before we came to power, all of the European funds for Bulgaria were blocked because of corruption, and this should be the question for Stanishev every time he opens his mouth".

\section{Weak populists}

Several prime ministers in our analysis who have previously been accused of populism turned out to be either weakly or not at all populist. This finding especially holds for the Kaczyński brothers in Poland, whose populist scores are very low. However, several undemocratic activities occurred during their tenure, including changing the constitutional set-up, curtailing the independence of the media and civil society, centralizing power and exaggerating external dangers (Kucharczyk and Wysocka 2008). Both brothers emphasized the moral deterioration of the Third Republic, which was, according to them, associated with corrupt elites. They favored the establishment of a post-communist Fourth Republic that would be founded on traditional values propagated by the Catholic Church. Jarosław Kaczyński adopted an "us versus them" attitude only in his 2007 campaign speech, while in his other speeches, although he focused on traditional values, he painted the world in generally pluralist terms. In his campaign 2007 speech his opponents were described as "bunch of liars", "oligarchs", and "multi-millionaires" who created "pathological structures and created privileges" that are "against the interests of Poles". Consequently, Third Republic elite members did not deserve to be a part of the morally superior Fourth Republic and the true is that the de-communization of members of the old communist elite and all the 
other elite that was against the moral principles of the Polish people become a centerpiece of Kaczyński's tenure (Bugaric 2008, 193).

Lech Kaczyński's discourse was similar to that of his brother and he also spoke about the moral deterioration of the Polish state that requires the restoration of "justice and honesty". However, he was more specific in referencing "the people', which is likely related to his direct presidential mandate. Unlike his brother, he was less prone to identifying any specific elite, which was likely a strategy to appeal to a broader electorate. Finally, in his campaign 2005 speech, systemic change favoring an increase in presidential powers to allow the fighting of "society's pathologies" was immediately tempered with pluralist ideas about "governing that belongs to the majority in the parliament and constitutional change that is dependent on the results of parliamentary elections". Our findings resonate with previous studies. Based on the level of state intervention and exclusiveness, Kaczyński's Law and Justice Party (PiS) scored low on populism (Jasiewicz 2008, 9). In fact, Polish populism can be best described as the process of elite replacement by positioning the alternative set of political actors as more authentic representatives of the people, rather than a comprehensive bottom-up conception of politics (Stanley 2012).

Simeon II, former Bulgarian king and prime minister from 2001 until 2005, was previously accused of populism, especially during his 2001 campaign (De Waele and Cholova 2011). Our data support this finding. In his 2001 speech, Simeon II adopted an "us versus them" narrative, presenting himself and his National Movement of Stability and Progress (NDSV) as "an agent of the people, sympathetic to their agony". However, his other speeches are generally pluralist and only mildly populist. He did propose an overthrow of the existing bipolar party model, which could be an element of populism, but he also failed to identify any specific enemy. He favored the reconciliation and unification of all political forces, which is usually a trait of pluralist discourse. Borisov, on the other hand, was more critical of the governing parties and presented himself as a "common man", which explains his higher numerical score compared to Simeon II (De Waele and Cholova 2011, 33).

Ivo Sanader in Croatia and Viktor Ponta in Romania were both accused of populism; however, according to the holistic grading their discourses are only weakly populist and generally pluralist. Sanader occasionally demonized the socialist opposition or referenced past enemies (largely from the former Yugoslav regime) but was generally pluralist and in favor of cooperating with international institutions and respecting international standards. Ponta adopted "the people versus the elite" attitude only during his campaign in 
2012. However, even then, his clash with then incumbent president Basescu ${ }^{15}$ appeared more relevant than his commitment to bottom-up politics. He accused Basescu and the previous ruling elite lead by Emil Boc of having communist roots, being corrupt, unwisely using European infrastructural funds and cutting back welfare. In his campaign 2012 speech, he claimed ["We cannot go back to their stealing, to their cowardice, to the way in which they sold our country piece by piece so that they can stay in power just a bit longer" (...) "they must be responsible for all the evil they have done" (...) "they must not be brought to Parliament, they must be brought to the Courts of Justice"]. At the same time, he portrayed himself and his socialist-liberal coalition as "the savior of Romanians, ready to fix past elite injustices". His other speeches were largely pluralist in nature with a clear tendency towards unifying political forces and were against further polarization or institutional conflicts.

Based on our data, populism among Baltic prime ministers is not popular. Einars Repše and Aigars Kalvītis in Latvia adopted a mild populist discourse when speaking of opposition parties and former Soviet regime as a conspiring elite, but are otherwise largely pluralist. This finding resonates with a comprehensive study of populism among Baltic parties that found little evidence of the success of populism. According to that study, the small size of political communities and individual interactions among elite members make populism an unattractive strategy, especially in Latvia and Estonia, while it may be somewhat more attractive in Lithuania where larger number of parties compete for power (Balcere 2014; Jakobson et al. 2012). Somewhat higher populist scores for two Latvian prime ministers deserve further investigation. Do personal characteristics make some individuals more prone to populism (which could explain the incidence of occasional populist individuals in populism's non- fertile settings)? Answering such research questions might benefit from political psychology that should be considered in the study of populism.

\section{The advantages and limitations of holistic grading}

Holistic grading as a specific type of textual analysis has several advantages compared to other methods, but it is not without its limitations. The ability

15 Ponta and his coalition attempted to impeach Basescu, alleging that he had breached the constitution and overstepped his authority. To be considered valid, the impeachment process had to be confirmed by referendum, which failed due to low voter turnout and Basescu continued as president. 
to not only identify but also demonstrate variation in the political discourse of individual leaders across time and space is an obvious contribution to the scientific literature. This permits the researchers of populism to move away from typical single case-oriented studies to comparisons between large numbers of cases. Data obtained by holistic grading further emphasize that only after systematic analysis of populism is carried out can we justifiably identify someone as a populist. As our data indicate, the speeches of many prime ministers previously accused of populism were graded low on the scale of populism, which fits them into only weak populist or pluralist discourse categories. Additionally, holistic grading not only relies on numerical scores to reveal someone's populism but also on qualitative data that extend our knowledge as to why particular leaders score high or low on a numerical scale.

Findings in this study also suggest that populism defined as a set of ideas is context-dependent and triggered by certain environment-related factors. For example, Czech Miloš Zeman was accused of populism during his 2013 presidential campaign yet our data confirmed he was not at all populist during his term as prime minister. The same holds for Hungarian Viktor Orbán who was moderately populist in his second term as prime minister, while generally pluralist during his first prime ministerial term. Further research should find ways to include context-dependent variables into the study of populism. An additional limitation of the method might be the potential bias on the side of coders with regard to how they perceive leaders' discourses when grading speeches after large time lapses. We overcome this potential bias by emphasizing to coders during training sessions that a particular political speech is always to be evaluated for what it is, instead of what it could be, given the political circumstances of each particular context. For example, we insisted that Orbán's earlier speeches were to be judged based only on the elements of each discourse present in the text, and not based on how populist Orbán may have sounded in a particular speech, taking into account current or past political and media presentations.

Finally, our analysis opens up avenues for solving old and new puzzles concerning populism. After learning how populist someone is we can investigate the reasons why that matters for politics. Thus, holistic grading has an immediate research impact on the study of populism's causes and consequences. Moreover, scientifically-relevant questions that follow from our analysis relate to the need to examine populism in settings otherwise not obviously fertile for its growth. Finally, the data in this study resonate with previous arguments about the relationship between populism and democratic violations. All the populist prime ministers in our dataset engaged to an extent 
in democratically dubious practices. However, the data in our study reveal that undemocratic experiments were not absent during non-populist prime ministerial terms. This suggests that we need to learn more about how exactly populism affects politics and if other intervening factors contribute to the relationship. Further research would benefit by focusing on the correlations between populist discourse and democratic violations. A political culture generally not conducive to democracy (rather than populism alone) might explain the occasionally undemocratic lapses of some political individuals. However, the consequences for democratic politics appear to be in most danger when undemocratic and populist mindsets coincide.

\section{CONCLUSION}

The study described in this paper involved the holistic grading as a specific technique of textual analysis of political speeches by CEE prime ministers. The result is a large dataset of political discourse among 27 contemporary prime ministers in eleven CEE countries during 30 prime ministerial terms. Populism is defined here as a set of ideas that include the holding of a Manichean worldview in which the people are juxtaposed against corrupt elites in a constant struggle for power. Consequently, populists advocate the overthrow of unjust elites and frequently resort to bellicose language when addressing political opponents. To distinguish between different political discourses besides populism we also considered pluralism, which rejects the Manichean worldview, reveres political differences, respects democratic standards and political opponents.

The ideational definition of populism guided the holistic grading of political speeches by each prime minister in order to express political discourse on a three-point numerical scale to denote strong or moderate populist or pluralist discourse. Systematic analysis of the political discourse of CEE prime ministers confirmed the existence of strong populist discourse in only one, and moderate populist discourse in five out of 27 CEE prime ministers. We also note the existence of stronger populist discourse during electoral campaigns, compared to actual prime ministerial tenures. This could be explained by prime ministers' tendency to abandon the pursuit of anti-elite rhetoric once they become part of the official elite. Our data support previous findings obtained by holistic grading (Hawkins 2009). The incidence, intensity and the distribution of populist discourse across different speech categories by CEE prime ministers compared to Latin American presidents are almost identical. All this leads to the conclusion that academic and media concerns about the 
prevalence of populist zeitgeist are slightly overrated.

Holistic grading is an efficient and reliable measurement technique for cross-regional comparisons of leaders' political discourse compared to other manually-coded methods of content analysis. The main contribution of the method is its ability to move the study of populism away from typically single case-oriented research to the comparison of large numbers of cases across time and space. Holistic grading facilitates the systematic study of populism and not only identifies but also signifies the intensity of populist discourse using a numerical scale. In addition, the qualitative data obtained by the method support the awarding of numerical scores, making it clearer why one particular discourse fits one or another category. The method's application is not limited to political speeches, but has potential for use in appraising other official (i.e. party manifestos) or unofficial (i.e. Facebook or Twitter) political texts. In addition, by testing the method on other types of political texts, future research could analyze how various context-related factors drive political discourse.

The systematic analysis of populist discourse using holistic grading has immediate implications for the study of populism's causes and consequences. Hitherto, research has speculated about the consequences populism has on politics, emphasizing its negative effect on democratic structures. The findings of this study confirm that such a relationship does exist. All the populist prime ministers resorted to some undemocratic practices during their terms. However, occasional democratic violations were also common among non-populist (or less populist) prime ministers. This suggests that more research is required to improve our knowledge about exactly how someone's populist discourse relates to democratic structure. The existence of a political culture generally not conducive to democracy rather than populism alone might explain the democratic violations of political individuals who engage in less intense populist discourse. Nevertheless, democratic structures are least secure when undemocratic and populist mindsets coincide. 


\section{REFERENCES}

Albertazzi, Daniele and Duncan McDonnell (eds). 2008. Twenty-first Century Populism: The Spectre of Western European Democracy. Palgrave Macmillan.

Akkerman, Agnes, Cas Mudde and Andrej Zaslove. 2013. "How populist are the people? Measuring populist attitudes in voters." Comparative Political Studies. doi: $10.1177 / 0010414013512600$

Balcere, Ilze. 2014. "Populism in the Manifestos of Latvian Political Parties: Increasingly Used but Ineffective?" Journal of Baltic Studies 45 (4): 477-97.

Bozóki, András. 2012. "The Illusion of Inclusion: Configurations of Populism in Hungary." http://cadmus.eui.eu/handle/1814/26934.

Bugaric, Bojan. 2008. "Populism, Liberal Democracy, and the Rule of Law in Central and Eastern Europe." Communist and Post-Communist Studies 41 (2): 191-203.

Bunce, Valerie J. and Sharon L. Wolchik. 2011. Defeating Authoritarian Leaders in Postcommunist Countries. Cambridge University Press.

Carpenter, Michael. "Slovakia and the Triumph of Nationalist Populism." Communist and Post-Communist Studies. 30 (2): 205-219.

Deegan-Krause, Kevin and Tim Haughton. 2009. "Toward a More Useful Conceptualization of Populism: Types and Degrees of Populist Appeals in the Case of Slovakia." Politics \& Policy 37 (4): 821-41.

De Waele, Jean-Michel and Blagovesta Cholova. 2011. "Bulgaria: A Fertile Ground for Populism?” Slovenská Politologická Revue, no. 1: 25-54.

Doyle, David. 2011. "The Legitimacy of Political Institutions Explaining Contemporary Populism in Latin America." Comparative Political Studies 44 (11): 1447-73. doi: $10.1177 / 0010414011407469$.

Fish, M. Steven. 1999. "End of Merciarism, The." East European Constitutional Review 8: 47.

Gallina, Nicole. 2008. Political Elites in East Central Europe: Paving the Way for "Negative Europeanisation"? Budrich UniPress.

Gallina, Nicole. 2010. "Looking beyond Democratic Façades: Political Elite Culture in Eastern Europe." In Warsaw East European Conference, Warsaw, July, 12-15.

Gallina, Nicole. 2011. "Political Elite Behavior in Eastern Central Europe: Provoking Populism and Nationalism?" Democracy, State and Society. European Integration in Central and Eastern Europe, 79-93.

Haughton, Tim. 2002. "Vladimír Mečiar and His Role in the 1994-1998 Slovak Coalition Government.” Europe-Asia Studies 54 (8): 1319-38.

Hawkins, Kirk A. 2009. "Is Chávez Populist? Measuring Populist Discourse in Comparative Perspective." Comparative Political Studies 42 (8): 1040-67.

Hawkins, Kirk A., Scott Riding and Cass Mudde. 2012. "Measuring populist attitudes." Working paper series, http://works.bepress.com/cas_mudde/72

Hawkins, Kirk A. and Cristóbal Rovira Kaltwasser. 2013. "Populism as an ideational concept." XXXI Congress of the Latin American Studies Association, Washington, DC, May 29-June 1 
Hawkins, Kirk A. and Bojana Kocijan. 2013. "Codebook for Measuring Populist Discourse among chief executives in CEE and Central Asia."

Jagers, Jan and Stefaan Walgrave. 2007. "Populism as Political Communication Style: An Empirical Study of Political Parties' Discourse in Belgium." European Journal of Political Research 46 (3): 319-45. doi:10.1111/j.1475-6765.2006.00690.x.

Jakobson, M. L. Oudekki-Nurk Ilze-Loone, Tőnis Anu-Saarts, and Rasa Zakeviciute. 2012. Populism in the Baltic States: A Research Report. Tallinn, Latvia: Tallinn University Institute of Political Science and Governance.

Jasiewicz, Krzysztof. 2008. "The New Populism in Poland: The Usual Suspects?" Problems of Post-Communism 55 (3): 7-25.

Kaehne, Axel and Rafael Riedel. 2008. "Poland's Opportunistic Democracy. The Kaczyński Years.”

Kriesi, Hanspeter. 2014. "The Populist Challenge." West European Politics 37 (2): 361-78.

Kucharczyk Jacek and Wysocka Olga. 2008. "Poland”. in Mesežnikov, Grigorij, Ol'ga Gyárfášová and Daniel Smilov (eds.)"Populist Politics and Liberal Democracy in Central and Eastern Europe." Institute for Public Affairs.

Lengyel, Gyorgy and Gabriella Ilonszki. 2012. " Simulated Democracy and PseudoTransformational Leadership in Hungary”. Historical Social Research. 37 (1):107126.

Levitsky, Steven and James Loxton. 2013. "Populism and Competitive Authoritarianism in the Andes." Democratization 20 (1): 107-36. doi:10.1080/13510347.2013.738 864.

Mesežnikov, Grigorij and Ol'ga Gyárfášová. 2008. "National Populism in Slovakia." Bratislava, Slovakia: Institute for Public Affairs (IVO).

Mesežnikov, Grigorij, Ol'ga Gyárfášová and Daniel Smilov. 2008. "Populist Politics and Liberal Democracy in Central and Eastern Europe." Institute for Public Affairs.

Mudde, Cas. 2004. "The Populist Zeitgeist." Government and Opposition 39 (4): $542-$ 63. doi:10.1111/j.1477-7053.2004.00135.x.

Mudde, Cas. 2007. Populist Radical Right Parties in Europe. Cambridge University Press.

Mudde, Cas and Cristóbal Rovira Kaltwasser. 2012. Populism in Europe and the Americas: Threat Or Corrective for Democracy?. Cambridge University Press.

Mudde, Cas and Cristóbal Rovira Kaltwasser. 2013. "Exclusionary vs. Inclusionary Populism: Comparing Contemporary Europe and Latin America." Government and Opposition 48 (02): 147-74.

Navia, Patricio and Ignacio Walker. 2010. "Political Institutions, Populism, and Democracy in Latin America." in Mainwaring, Scott and Timothy R. Scully (eds.) Democratic Governance in Latin America, Stanford University Press. 245-65.

Pirro, Andrea L. 2014. "Populist Radical Right Parties in Central and Eastern Europe: The Different Context and Issues of the Prophets of the Patria." Government and Opposition. Vol. 49 (04). 600 - 629. 
Rizman, Rudolf M. 2006. "Towards Democratic Consolidation (The case of Slovenia)." in Krasteva, Anna and Francesco Privitera (eds.) Democratization in Post-Communist Transition Processess in the 1990s: Lights and Shadows. Longo Editore Ravenna. 27-49.

Rooduijn, Matthijs and Teun Pauwels. 2011. "Measuring Populism: Comparing Two Methods of Content Analysis." West European Politics. 34 (6): 1272-1283.

Rovira Kaltwasser, Cristóbal. 2014. "The Responses of Populism to Dahl's Democratic Dilemmas.” Political Studies 62 (3): 470-87. doi:10.1111/1467-9248.12038.

Rupnik, Jacques. 2007. "From Democracy Fatigue to Populist Backlash." Journal of Democracy 18 (4): 17-25.

Schumacher, Gijs and Matthijs Rooduijn. 2013. "Sympathy for the 'devil'? Voting for populists in the 2006 and 2010 Dutch general elections." Electoral Studies. 32 (1): 124-133

Seligson, Mitchell A. 2007. "The Rise of Populism and the Left in Latin America." Journal of Democracy 18 (3): 81-95.

Stanley, Ben. Down With the Pseudo-Elite! Populism as a Strategy for Elite Replacement in Post-Communist Poland'. Paper presented at the International Political Science Assocation XXII World Congress of Political Science, Panel RC02.318 'Elites and Populist Leaders', Madrid, 7-12 July 2012.

Tupy, Marian L. 2006. "The Rise of Populist Parties in Central Europe: Big Government, Corruption, and the Threat to Liberalism." Development Policy Analysis No 1.

Vasilopoulou, Sofia, Daphne Halikiopoulou and Theofanis Exadaktylos. 2014. "Greece in Crisis: Austerity, Populism and the Politics of Blame." Journal of Common Market Studies. 52 (2): 388-402. 